\title{
Proximate composition analysis of chicken burgers from night market stalls and selected fast-food restaurants
}

\author{
${ }^{1}$ Unzil, N.A. ${ }^{1,2,3, *}$ Azlan, A. and ${ }^{1,3}$ Sultana, S \\ ${ }^{1}$ Department of Nutrition and Dietetics, Faculty of Medicine and Health Sciences, 43400 UPM Serdang, \\ Selangor, Malaysia \\ ${ }^{2}$ Research Centre of Excellence for Nutrition and Non-Communicable Diseases, Faculty of Medicine and \\ Health Sciences, Universiti Putra Malaysia, UPM Serdang, 43400 UPM Serdang, Selangor, Malaysia \\ ${ }^{3}$ Halal Products Research Institute, Universiti Putra Malaysia, 43400 UPM UPM Serdang, Selangor, \\ Malaysia
}

\author{
Article history: \\ Received: 25 August 2020 \\ Received in revised form: 2 \\ October 2020 \\ Accepted: 17 November 2020 \\ Available Online: 13 \\ February 2021

\section{Keywords:} \\ Protein, \\ Carbohydrate, \\ Fat, \\ Energy, \\ Dietary fibre
}

\section{DOI:}

https://doi.org/10.26656/fr.2017.5(1).469

\begin{abstract}
This study was aimed to determine and compare the proximate composition of chicken burgers from night market stalls and selected fast-food restaurants. The methods used for determination of proximate composition were AOAC Official Methods 973.48, 960.39, 991.43, 990.19 and 999.11 for protein, fat, fibre, moisture and ash, respectively except total available carbohydrate. The energy content of all samples was calculated based on 4, 4 and $9 \mathrm{kcal} / 100 \mathrm{~g}$ for carbohydrate, protein and fat, respectively. The protein content of burger samples from fast-food restaurant ranged $14.48-18.6 \%$, whereas the samples from night market stalls had protein content ranged $13.26 \%-19 \%$. Fat contents of burger samples from fast-food restaurant and night market stalls were $18.57-19.11 \%$ and 26.33 $28.0 \%$, respectively. There were statistically significant differences $(p<0.05)$ in the percentage of insoluble dietary fibre, but no significant differences were found for soluble and total dietary fibres in the burger samples between night market stalls and the restaurants. Night-stall burger samples had higher fibre content $(0.14-0.20 \%)$ than the fastfood restaurant samples which ranged $0.11-0.16 \%$. Burger samples from the fast-food restaurant had higher carbohydrate content ranged between $17.77 \%$ and $18.55 \%$ compared to night stall samples (7.70-8.94\%). Also, the energy content of all burger samples ranged 296-360 kcal. There were significant differences for the protein, fat, carbohydrate, energy and ash content of the burger samples between night market stalls and fast-food restaurants but not for moisture and fibre content. The findings indicated that the nutritional composition of burger samples varied among different locations where a variation in preparation method was observed.
\end{abstract}

\section{Introduction}

At present, the consumption of ready-to-eat foods from the nearest food court, groceries and restaurant have drastically increased due to the increasing volumes of works and extension of possible business hours. Bielemann et al. (2015) stated that $50.0 \%$ of daily caloric intake among young adults was contributed by the consumption of ultra-processed food. Furthermore, a study conducted in Selangor, Malaysia by Asma (2014) showed that $38.0 \%$ of total energy from daily energy intake comes from ultra-processed foods products. Thus, these are lead people more dependent on ready-to-eat foods, such as frankfurters, burgers, pizzas, meatballs, soups, creams, candies, and cookies (Ali et al., 2014).
Hence, the consumers are paying great attention to the quality and ingredients of ready-made and packaged foods due to the health concern.

In Malaysia, due to urbanisation, many Malaysians preferred food that easy to serve and eat like fast-food and ready-to-eat processed foods that are convenient to them especially for those living in urban areas (Asma, 2014).

According to Ramadhan et al. (2011), chicken patty is one of the processed chicken-based products that has been distributed through wholesalers and restaurants that most preferred by the population. There are four major food sub-category of burger patty in the fast-food 
industry which are beef, fish, chicken and vegetarian patties (The Food Monitoring Group, 2012). According to Mikhail et al. (2014), chicken meat is the most preferred meat protein source of a ready-to-eat meal. Comparing to the other types of meat, chicken meat is enriched with important nutrients. Chicken burgers are generally greatest in their colour, hardness, springiness and chewiness compared to other poultry burgers such as duck burger (Ramadhan et al., 2012). A study by Wong et al. (2012) found that burger is one of the most popular fast-food in Malaysia although it is a typical western diet. They also stated that burgers can be easily found at western restaurants, kiosks, night markets, street vendors and stalls in the country. Malaysian commercial chicken burgers complied with the Food Act 1983 of Malaysia and contained different levels of chemical compositions, textural characteristics and colour (Ramadhan et al., 2011). Appropriate product labelling with proper description is very conclusive for consumers because it respects personal food choice, safeguards the public health, assures religious belief and fair trade (Ali et al., 2015). Thus, the social, health, and business interests in chicken burgers are enormous, and there should be a trustworthy method to determine the proximate composition of chicken burgers to provide consumers baseline information on carbohydrate, protein and fat content in the chicken burger.

Up-to-this-date, various analytical approaches have been documented to determine the functional ingredients of meat products but no satisfactory information available for chicken burgers. However, most of the previous studies are unsuitable because they only focused on beef burgers. In this study, the chicken burgers from selected night market stalls and fast-food restaurants were determined for their proximate content. The generated data can be added to the local Food Composition Databases. Therefore, the proximate composition of chicken burger from selected night market stalls and fast-food restaurants was determined in this study.

\section{Materials and methods}

\subsection{Preparation of samples}

Samples of chicken burgers were purchased in duplicate on three different days from two different locations (Serdang, Selangor and Putrajaya, Wilayah Persekutuan) which were randomly selected. A total of five different chicken burgers from the selected night market stalls (ordinary chicken burger, special chicken burger, double special chicken burger) and two selected fast-food restaurants (ordinary chicken burger) were purchased. The weight of the burger was 154.0 to 169.0 $\mathrm{g}$ per set and whole burger ingredients were used for analysis. The chicken burgers from fast-food restaurants were labelled as CB1 and CB2, and the chicken burgers from night market stalls were labelled as CB3-CB5. All the meat samples were cut into the smallest possible pieces using different surgical blades. Afterwards, the homogenised samples were freeze-dried and keep for further analysis. The lyophilised samples were ground into a powder and stored at $-20^{\circ} \mathrm{C}$ before further analyses. Approximately $5 \mathrm{~g}$ of the samples were taken to determine moisture content.

\subsection{Determination of fat content}

Fat content was determined based on the Soxhlet extraction method by using AOAC Official Method 960.39 (AOAC 2016). Instead, Fat content was measured by weight loss of the sample or by weight of the fat removed (Min and Ellefson 2010). Each of the experiment was run in triplicates by using EME6 0500/ CEBX6 Multi (Extraction) Mantles soxhlet system (Electrothermal, UK).

\subsection{Determination of protein content}

Kjeldahl Method was used to determine protein content which based on the standard procedure in AOAC Official Method 973.48 (AOAC 2016). In this method is performed based on an automated Kjeltec instrument (Foss, Germany) to determine protein content in burger samples. All tests were done in triplicates.

Briefly, burger samples were weighed approximately to $1 \mathrm{~g}$ and transferred into a digestion tube containing two digestion tablets and later added with $12 \mathrm{~mL}$ of concentrated sulphuric acid. Then, the mixture was digested at $420^{\circ} \mathrm{C}$ for 60 mina until clear with a bluegreen solution formed. After the digestion, the digestion tube was left to cool for 20 mina, added with $30 \mathrm{~mL}$ of $4 \% \mathrm{H}_{3} \mathrm{BO}_{3}$ and Tashiro's indicator. The cool digest was diluted by adding $80 \mathrm{~mL}$ distilled water. A 4 mins distillation was done by addition of $50 \mathrm{ml}$ of $40 \% \mathrm{NaOH}$ into the digestion tube. Finally, the distillate was titrated with a standardised $0.2 \mathrm{~N} \mathrm{HCl}$ until a pink or grey point was achieved. The blank was carried out to test the colour change of Tashiro's indicator.

The protein was calculated based on equation 1:

Nitrogen content, $\%$ by weight $=\frac{(\mathrm{t}-\mathrm{b}) \times 0.2 \times 14}{1000 \times \mathrm{w}_{\text {sample }}} \times 100 \%$

Where $\mathrm{t}=$ titration volume for sample $(\mathrm{mL}), \mathrm{b}=$ titration volume for blank $(\mathrm{mL}), 0.2=$ normality of titrant, $\mathrm{HCl}(\mathrm{mol} / \mathrm{l}), 14=$ atomic mass of nitrogen, $\mathrm{w}_{\text {sample }}$ $=$ weight of sample taken $(\mathrm{g})$. 


\subsection{Determination of dietary fibres}

The enzymatic-gravimetric method was used to determine total, soluble and insoluble dietary fibres which were based on AOAC Official Method 991.43 (AOAC 1995). All the samples were determined in triplicate by using Foss Fibertec E 1023 (Foss, Denmark).

Briefly, the $1 \mathrm{~g}$ samples were added to $50 \mathrm{~mL}$ of phosphate buffer at $\mathrm{pH} 6.0$ in the incubation flask. Next, $100 \mu \mathrm{L}$ of $\alpha$-amylase was added to the mixture and it was placed in a boiling water bath. Then, $100 \mu \mathrm{L}$ of protease solution was added into each incubation flask and incubated at $60^{\circ} \mathrm{C}$ for 30 mins with continuous agitation before the addition of $0.325 \mathrm{~N} \mathrm{HCl}$ and $\mathrm{pH}$ was adjusted to 4.0-4.6. The mixture in the flask was then added with $200 \mu \mathrm{L}$ of amyloglucosidase and incubated for another 30 mins at $60^{\circ} \mathrm{C}$ with continuous agitation.

The insoluble dietary fibre (IDF) was determined by adding a few drops of distilled water that function to wet and to redistribute tarred Celite in the crucible. Suction was used to withdraw Celite into an even mat. A Fibertec filtration instrument was then used to attach the crucibles and incubation flasks. The entire enzyme that has been digested was filtered through crucible into receiver flask. The incubation flask was rinsed and washed two times with $10 \mathrm{ml}$ of distilled water. After that, all filtrates were pooled. After washing, the crucible that was moved to the upper suction system. The sample was dried overnight in an oven at $105^{\circ} \mathrm{C}$. Finally, the dietary fibre residue and celite in the crucible were weighed and the residue weight was calculated by subtracting the weight of dry crucible and celite. The ash and protein content in the residue was calculated to determine the IDF.

To determine soluble dietary fibre (SDF), $280 \mathrm{~mL}$ of $95 \%$ ethanol was heated, and it was used to rinse down all residues around the wall of the receiver flask. After that, the precipitate was left for an hour at room temperature. Subsequently, the alcoholic heated enzyme digest was filtered through the crucible. All the residue needs to be washed three times using $20 \mathrm{~mL}$ of $78 \%$ ethanol and two times with $15 \mathrm{~mL}$ of acetone. The crucible was dried overnight in an oven at $105^{\circ} \mathrm{C}$. The residue was weight and calculated by subtracting the weight of dry crucible with celite. The total dietary fibre was then calculated.

\subsection{Determination of ash content}

Ash content of the samples was determined using dry ashing method AOAC Official Method 999.11 (AOAC 2016). Ashing of burger sample (10 g) was done in a Thermo Scientific Thermolyne 62700 muffle furnace at $550^{\circ} \mathrm{C}$. Before ashing, the crucible was dried in an oven at $105^{\circ} \mathrm{C}$ for $3 \mathrm{hrs}$.

\subsection{Determination of moisture content}

Moisture content was determined by using the air oven drying method by AOAC Official Method 990.19 (AOAC 2016). All the samples were measured in triplicate. The measurement was done by drying of the samples in a Model 600 air oven (Memmert, Germany) at $105^{\circ} \mathrm{C}$ for overnight. The dish was then cooled in a desiccator and weighed.

\subsection{Determination of carbohydrate content}

The carbohydrate content was calculated using the differential weight of all compounds (Ramadhan et al., 2012). The value was obtained by subtracting with the percentages of all other components such as moisture, protein, fat and ash.

\subsection{Determination of energy content}

The energy content of the burger samples was calculated by multiplying the amounts of carbohydrate, protein and fat with constant values of 4,4 and $9 \mathrm{kcal}$, respectively. Then, a sum up of these values was obtained for the total energy of each burger sample. This technique was used to quantify the total energies in food and beverages should be easy and convenient and not required special manipulation of the dataset (Ledikwe et al., 2005).

\subsection{Statistical analysis}

All data were expressed as mean \pm standard deviation (SD) and were analysed using IBM SPSS Version 22. All burger samples were analysed in triplicate to increase the validity and accuracy of the results. The comparison was made based on the analysis of variance (ANOVA) coupled with Tukey's range test. A statistically significant difference was set at $\mathrm{p}<0.05$.

\section{Results and discussion}

\subsection{Physical characteristics of chicken burgers}

The physical characteristics of chicken burger samples from the selected night market stalls and fastfood restaurants were varied (Table 1). The chicken burger samples (CB1-CB5) had a diameter ranged between $10 \mathrm{~cm}$ and $12.0 \mathrm{~cm}$. Besides the diameter, other characteristics that differentiate the chicken burgers include types and amounts of vegetables and sauce added. From the observation, a low amount of vegetable was added to the burgers from fast-food restaurants compared to the night market stall burgers. In fact, burgers from the fast-food restaurant have only one or two slices of lettuce compared to the night market stall 
burgers. Also, burgers from night market stalls have no standardised amount of vegetables added. The texture of the chicken patties might be influenced by the quality of meat and the processing methods (Ramadhan et al., 2011). Moreover, the presence of seasoning on the chicken patty could alter the proximate content of the burgers (Babji et al., 2000).

Table 1. Physical characteristic of chicken burger samples

\begin{tabular}{ccc}
\hline Burger sample & Diameter $(\mathrm{cm})$ & Weight $(\mathrm{g})$ \\
\hline CB1 & $12.0 \pm 0.01^{\mathrm{a}}$ & $154.05 \pm 0.54^{\mathrm{a}}$ \\
CB2 & $11.0 \pm 0.01^{\mathrm{b}}$ & $169.88 \pm 0.81^{\mathrm{b}}$ \\
CB3 & $10.0 \pm 0.01^{\mathrm{c}}$ & $156.02 \pm 4.89^{\mathrm{a}, \mathrm{c}}$ \\
CB4 & $10.5 \pm 0.01^{\mathrm{d}}$ & $157.34 \pm 10.24^{\mathrm{a}, \mathrm{c}}$ \\
CB5 & $10.9 \pm 0.01^{\mathrm{b}}$ & $163.89 \pm 7.98^{\mathrm{b}, \mathrm{c}}$ \\
\hline
\end{tabular}

Values are expressed as mean \pm standard deviation of two burger samples. Values with different superscript in the column are significantly different $(\mathrm{p}<0.05)$.

\subsection{Moisture content}

Table 2 shows the moisture content of chicken burger samples from the selected night market stalls and fast-food restaurants. The water content was assessed based on its fresh weight. The water content of the samples (CB1-CB5) ranged between $45 \%$ and $60 \%$. Our findings showed that $\mathrm{CB} 1$ had the highest moisture content followed by CB4, CB5, CB3 and CB2. However, there were statistically no significant differences between the chicken burger samples moisture content as determined by one-way ANOVA, $(p<0.05)$. Overall, burger samples from both fast-food restaurants had the highest and the lowest moisture content.

Table 2. Moisture and ash content of chicken burger samples

\begin{tabular}{ccc}
\hline Burger sample & Moisture $(\%)$ & Ash $(\mathrm{g})$ \\
\hline CB1 & $45.32 \pm 4.15^{\mathrm{a}}$ & $3.75 \pm 0.05^{\mathrm{c}}$ \\
CB2 & $40.00 \pm 4.92^{\mathrm{a}}$ & $3.58 \pm 0.09^{\mathrm{b}}$ \\
CB3 & $40.00 \pm 7.56^{\mathrm{a}}$ & $3.93 \pm 0.04^{\mathrm{d}}$ \\
CB 4 & $45.00 \pm 0.75^{\mathrm{a}}$ & $4.28 \pm 0.05^{\mathrm{e}}$ \\
CB5 & $42.00 \pm 1.11^{\mathrm{a}}$ & $3.10 \pm 0.07^{\mathrm{a}}$ \\
\hline
\end{tabular}

Values are expressed as mean \pm standard deviation, $\mathrm{n}=3$. Values with different superscript within the column indicate significant difference at $\mathrm{p}<0.05$.

Our findings showed that there is a wide range of moisture content in the burger samples. Comparing the CB1 and CB2 from both fast-food restaurants, there is an inconsistency in the burger preparation. According to Babji et al. (1995), moisture content of chicken burgers selling in Malaysia was generally between $42 \%$ and $65 \%$ of their wet weight which is similar to values obtained from this study. The chicken burgers from the selected night market stalls and fast-food restaurants have an acceptable range of moisture compared to the findings reported in the literature. The high moisture content could be due to the presence of fresh vegetables added to the burger which contained a high level of moisture.

\subsection{Ash content}

Table 2 depicts the ash content of chicken burger samples obtained from the selected night market stall and fast-food restaurants which ranged between $3.0 \%$ and $4.5 \%$. The ash content was assessed based on its wet weight and expressed as the percentage of its dry weight. There were statistically significant differences among the chicken burger samples determined by one-way ANOVA $(p<0.05)$. The post-hoc test revealed that the ash content of CB5 was significantly lower than CB4.

Based on the results obtained from a previous study, the ash content of the locally made chicken burgers ranged from $1.8 \%$ to $2.4 \%$ (Babji et al., 1995). According to Babji et al. (2000), the ash content of local and franchise chicken burgers ranged from $1.5 \%$ to $2.1 \%$. Besides, the ash content of uncooked commercial chicken patties in Malaysia was ranged from 1.5\% to 3.0\% (Ramadhan et al., 2011). Apart from Malaysia, the ash content of chicken burgers from Kuwait ranged from $1.5 \%$ to $2.9 \%$ (Al-Bahouh et al., 2012). In the present study, the samples had ash content higher than the values reported in previous studies. According to Al-Bahouh et al. (2012), the high ash value could be due to the addition of spices as seasoning, high fibre vegetables, starches, cereals, soy proteins and salt. Soft bone and other chicken parts in the patty could also increase the ash content due to the presence of calcium and other macrominerals (Babji et al., 2000).

\subsection{Protein content}

Table 3 shows the protein content of the burger samples. The protein content was determined based on its dry weight and expressed as the percentage of dry weight. Protein content in chicken burger samples ranged between $13.0 \%$ and $19.0 \%$. The results showed that CB5 had the highest protein content followed by CB2, CB4, $\mathrm{CB} 1$ and CB3. There were statistically significant differences in protein content between the burger samples at $\mathrm{p}<0.05$. The post-hoc test also showed that

Table 3. Protein, fat and carbohydrate content of chicken burger samples

\begin{tabular}{cccc}
\hline Burger sample & Protein $(\%)$ & Fat $(\%)$ & Carbohydrate $(\%)$ \\
\hline CB1 & $14.48 \pm 0.74^{\mathrm{a}, \mathrm{b}}$ & $18.57 \pm 1.83^{\mathrm{a}}$ & $17.77 \pm 0.68^{\mathrm{b}}$ \\
CB2 & $18.90 \pm 0.35^{\mathrm{c}}$ & $19.11 \pm 1.11^{\mathrm{a}}$ & $18.55 \pm 1.09^{\mathrm{b}}$ \\
CB3 & $13.26 \pm 0.74^{\mathrm{a}}$ & $27.20 \pm 0.04^{\mathrm{b}}$ & $8.48 \pm 1.28^{\mathrm{a}}$ \\
CB 4 & $15.31 \pm 0.27^{\mathrm{b}}$ & $26.33 \pm 0.83^{\mathrm{b}}$ & $8.94 \pm 0.31^{\mathrm{a}}$ \\
CB5 & $19.00 \pm 0.40^{\mathrm{c}}$ & $28.00 \pm 0.43^{\mathrm{b}}$ & $7.70 \pm 0.26^{\mathrm{a}}$ \\
\hline
\end{tabular}

Values are expressed as mean \pm standard deviation, $\mathrm{n}=3$. Values with different superscript within the column indicate significant difference at $\mathrm{p}<0.05$. 
the protein content of $\mathrm{CB} 3$ was significantly lower than CB2 and CB5.

According to Babji et al. (1995), the protein content of the locally processed burgers ranged from $10 \%$ to $16 \%$. Another study by Babji et al. (2000) showed that the protein content of local and franchise chicken burgers in Malaysia ranged from $12.0 \%$ to $16 \%$ and $18.0 \%$ to $22.7 \%$, respectively. In this study, the samples had protein content within the ranges reported in the literature. Al-Bahouh et al. (2012) also reported that local and imported chicken burgers from Kuwait have high amounts of protein which fulfilled the Kuwait Standard (1187/1999), where amounts corresponding to the minimum level of protein in burgers of above $15 \%$.

The protein values obtained in the present study seems to be comparable to the values reported by previous studies. Apart from this, the protein content of uncooked commercial chicken burgers ranged between $11.0 \%$ and 19\% (Ramadhan et al., 2011). Malaysian Food Regulations require a minimum level of nitrogen in organic form for processed meat products to be $1.7 \%$ which is equal to $10.625 \%$ protein (Food Act 1983 and Food Regulations 1985). Therefore, all commercial chicken burgers have adequate protein content and comply with the Malaysian Food Regulations 1985.

\subsection{Fat content}

In this study, the fat content of chicken burger samples was assessed based on its dry weight and expressed as the percentage of dry weight (Table 3 ). The results showed that fat content in the burger samples ranged between $18.0 \%$ and $28.0 \%$. CB5 had the highest fat content, whereas CB1 recorded the lowest fat content. The fat content of other burger samples was $19.11 \%$, $26.33 \%$ and $27.2 \%$ for CB2, CB4 and CB3, respectively.

The data obtained from one-way ANOVA revealed that the percentages of fat in the burger samples were significantly different at $p<0.05$. Post-hoc tests on the other hand showed no significant differences in the percentages of fat between $\mathrm{CB} 1$ and $\mathrm{CB} 2$ from the selected fast-food restaurants and among CB3, CB4 and CB5 from the night market stalls. Compared to the fat content of local burger reported by Babji et al. (2000), the burger samples from the selected fast-food restaurants and night market stalls had higher levels of fat than the reported values $(12 \%$ to $23 \%)$, whereas fat content of the franchise chicken burger reported in the previous study ranged from $5 \%$ to $8 \%$. All chicken burgers studied have higher amounts of fat than the burger samples reported in the literature.

The high fat content of chicken burger samples reported in this study could be due to the unhealthy way of patty grilling and extra fat-containing spread added to the burger samples. Al-Bahouh et al. (2012) found that the fat content of the chicken burgers from Kuwait ranged from $3.0 \%$ to $16 \%$. From their finding, the lowfat content in the burger might be due to the fat-free patty grilling method and the chicken patties with excessive fat removed. The increasing consumer's health awareness in recent years attributes to the high demand for a low calories burger in the food industry. In another study by Ramadhan et al. (2011), uncooked commercial chicken patties had fat content ranged from $9 \%$ to $21 \%$. Some of the chicken patties in their study were considered having low-fat content because a high moisture content was detected in the patties. In a nutshell, locally produced chicken burgers have lower protein and higher fat content than the franchised burgers (Babji et al., 1995).

\subsection{Carbohydrate content}

In this study, total available carbohydrate of the burger samples was calculated as the difference between the amount of carbohydrate and the total amounts of all other components determined. As shown in Table 3, the carbohydrate content of the burger samples ranged between $7.0 \%$ and $19.0 \%$. CB2 had the highest carbohydrate content (18.55\%) followed by CB1 (17.77\%), CB4 (8.94\%), CB3 (8.48\%) and CB5 (7.70\%). Based on the ANOVA result, there were significant differences $(p<0.05)$ in the percentage of total carbohydrate between the burger samples. However, post -hoc tests showed no significant differences in the percentage of total carbohydrate between CB1 and CB2 from the selected fast-food restaurants and between burger samples from the night market stalls.

According to Babji et al. (2000), local and franchised chicken burgers had $2-13 \%$ of carbohydrate. In the present study, the carbohydrate content of the samples was much higher than the values reported by Babji et al. (2000). However, the carbohydrate content of chicken burgers from Kuwait was 3-25\% (Al-Bahouh et al., 2012). Besides these findings, the carbohydrate content of uncooked commercial chicken patties in Malaysia ranged from $2 \%$ to $22 \%$ (Ramadhan et al., 2011).

\subsection{Total, soluble and insoluble dietary fibres content}

Table 4 shows the total, soluble and insoluble dietary fibres content of chicken burgers from the selected night market stalls and fast-food restaurants which ranged 0.11 $-0.20 \%, 0.02-0.05 \%$ and $0.05-0.17 \%$, respectively. CB5 from the night market stall had the highest total fibre content followed by CB2, CB3 and CB4. CB1 from the fast-food restaurant had the lowest total fibre content. 
The statistical results showed that there were significant differences in the percentages of insoluble dietary fibre, and no significant differences were observed for soluble and total dietary fibres content between the burger samples at $p \geq 0.05$. However, posthoc test showed a significant difference in the percentage of insoluble dietary fibre between CB1 and CB2. The results also demonstrated that insoluble dietary fibre content of CB1 was significantly lower for than $\mathrm{CB} 2$ and CB5.

Table 4. Total dietary fibre, soluble and insoluble dietary fibres content of chicken burger samples

\begin{tabular}{cccc}
\hline $\begin{array}{c}\text { Burger } \\
\text { sample }\end{array}$ & $\begin{array}{c}\text { Soluble dietary } \\
\text { fibre (\%) }\end{array}$ & $\begin{array}{c}\text { Insoluble dietary } \\
\text { fibre (\%) }\end{array}$ & $\begin{array}{c}\text { Total dietary } \\
\text { fibre (\%) }\end{array}$ \\
\hline CB1 & $0.05 \pm 0.03^{\mathrm{a}}$ & $0.05 \pm 0.03^{\mathrm{a}}$ & $0.11 \pm 0.06^{\mathrm{a}}$ \\
$\mathrm{CB} 2$ & $0.02 \pm 0.00^{\mathrm{a}}$ & $0.14 \pm 0.01^{\mathrm{b}}$ & $0.16 \pm 0.01^{\mathrm{a}}$ \\
$\mathrm{CB} 3$ & $0.02 \pm 0.00^{\mathrm{a}}$ & $0.12 \pm 0.03^{\mathrm{a}, \mathrm{b}}$ & $0.14 \pm 0.03^{\mathrm{a}}$ \\
$\mathrm{CB} 4$ & $0.02 \pm 0.00^{\mathrm{a}}$ & $0.12 \pm 0.01^{\mathrm{a}, \mathrm{b}}$ & $0.14 \pm 0.01^{\mathrm{a}}$ \\
CB5 & $0.03 \pm 0.01^{\mathrm{a}}$ & $0.17 \pm 0.01^{\mathrm{b}}$ & $0.20 \pm 0.00^{\mathrm{a}}$ \\
\hline
\end{tabular}

Values are expressed as mean \pm standard deviation, $\mathrm{n}=3$. Values with different superscript within the column indicate significant difference at $\mathrm{p}<0.05$.

As reported in a previous study (Babji et al., 2000), the levels of total dietary fibre of Malaysian chicken burgers were $1.56-1.77 \%$, whereas the franchise chicken burgers had total dietary fibre of $0.35-0.41 \%$. In the present study, all samples had lower total dietary fibre than the burger samples reported by previous study (Babji et al., 2000). The difference may be due to the fact that different quality of chicken patties was used. The incorporation meat products with dietary fibre from cornsilk from the plant as a functional ingredient help to improve cooking yield increases the protein content and reduce the amount of fat (Wan Rosli et al. 2011). A study by Ramadhan et al. (2011) on physicochemical characteristics of Malaysian chicken burgers showed the use of dietary fibre in meat processing which is concerning about the economical, nutritive and technological issues. Besides the burger patties, addition of vegetables such as salad leaves and slices of cucumber and tomato attributed to the high fibre content.

Dietary fibres are naturally present in cereals, legumes, fruits and vegetables (Kim and Paik, 2012). Vegetables have high fibre content and serve as natural sources of fibre (Gupta et al., 2005). In this study, the low fibre content of chicken burger from the fast-food restaurant could be due to only a small amount of vegetable was added into the burger. According to Kim and Paik (2012), the main sources of dietary fibre used in meat processing are grains and cereals such as wheat, oat, rye and rice. Hence, there are two types of dietary fibre incorporated to meat products such as soluble fibre found in beans and psyllium husk and insoluble fibre from the bran of the grain used. The addition or enhancement of dietary fibres in chicken patties slightly affect the patty quality where insoluble fibre increases the consistency of meat products by water fixation and fat absorption (Ladero et al., 2012). Based on the nutrition facts from the Burger King USA Nutritionals (2016), the dietary fibre content in the chicken burger is $2 \mathrm{~g}$ per serving size which has $0.9 \%$ dietary fibre in the whole chicken burger. Thus, the findings of this study revealed that chicken burgers available in Malaysia have low dietary fibres content. The amounts of dietary fibre in the chicken burger samples are varied due to a standardised method for burger preparation is not available in Malaysia.

\subsection{Total energy content}

The total energy of the chicken burger samples was calculated and expressed as kilocalories (kcal) per $100 \mathrm{~g}$ edible portion. The energy content of the samples ranged between $296.13 \mathrm{kcal}$ and $358.8 \mathrm{kcal}$ (Table 5). The result showed that CB5 from night market stall had the highest energy content $(358.8 \mathrm{kcal})$ followed by CB4 (333.97 kcal), CB3 (331.76 kcal) and CB2 (320.59 kcal). The burger sample that was obtained from a selected fastfood restaurant, CB1, recorded the lowest energy content $(296.13 \mathrm{kcal})$.

Table 5. Energy content of chicken burger samples

\begin{tabular}{cc}
\hline Burger sample & Energy (kcal) \\
\hline CB1 & $296.13 \pm 25.86^{\mathrm{a}}$ \\
CB2 & $320.59 \pm 15.01^{\mathrm{a}, \mathrm{b}}$ \\
CB3 & $331.76 \pm 5.67^{\mathrm{a}, \mathrm{b}}$ \\
CB4 & $333.97 \pm 14.99^{\mathrm{a}, \mathrm{b}}$ \\
CB5 & $358.80 \pm 11.98^{\mathrm{b}}$ \\
\hline
\end{tabular}

Values are expressed as mean \pm standard deviation, $\mathrm{n}=3$. Values with different superscript within the column indicate significant difference at $\mathrm{p}<0.05$.

One-way ANOVA showed that the energy content of the five samples was significantly different at $p<0.05$. The post-hoc tests revealed that the energy content was significantly different between $\mathrm{CB} 1$ and $\mathrm{CB} 5$, but no significant differences between $\mathrm{CB} 2, \mathrm{CB} 3$ and CB4. According to nutrition facts from the Burger King USA Nutritionals (2016), the energy content in the whole chicken burger is $420 \mathrm{kcal}$ while for McDonald's USA Nutrition Facts (2015) is $370 \mathrm{kcal}$. As compared to the values reported in the literature, burger samples of this study have lower energy content. Moreover, the high energy content in CB5 could be due to the chicken burger was prepared with double patties. 


\section{Conclusion}

The nutritional values of the selected chicken burger samples from night market stalls and the fast-food restaurants are varied due to the different methods of preparation. Chicken burgers from the selected fast-food restaurants had higher percentages of protein and lower fat content than the burgers purchased from the night market stalls. Nevertheless, most of the chicken burgers complied with the Food Regulations of Malaysia, especially in fat and protein content. This study is important in providing insights into the nutrient composition of chicken burgers from night market stalls and fast-food restaurants in Malaysia. The information may be useful for the public in choosing a healthier burger. Available data on proximate composition of chicken burgers also assist consumers to make a healthier choice for maintaining a healthy lifestyle. Lastly, this finding gives a better and clearer understanding of the proximate composition of chicken burgers available in Malaysia.

\section{Acknowledgement}

We thank all laboratory staffs from the Department of Nutrition and Dietetics, Faculty of Medicine and Health Sciences, Universiti Putra Malaysia for their contribution in performing this research.

\section{References}

Asma, A. (2014). An exploration of dietary patterns and the relationship with obesity in the Malaysian population. United Kingdom: University of Southampton. $\mathrm{PhD}$ dissertation.

AOAC (Association of Official Agricultural Chemists). (1995). Method 991.43: total, soluble, and insoluble dietary fiber in foods. USA: AOAC.

AOAC (Association of Official Agricultural Chemists). (2016). Official Methods of Analysis of AOAC International. 20th ed. Rockville, USA: AOAC International.

Babji, A.S., Chempaka, S. and Yusof, M. (1995). The nutritional value of some processed meat products in Malaysia. Malaysian Journal of Nutrition, 1(1), 8394.

Babji, A.S., Nuri, M.N., Suherman, J. and Chempaka, M.Y.S. (2000). Quality assessment of local and franchise beef and chicken burgers. Pertanika Journal of Tropical Agricultural Science, 23(2), 103112.

Bielemann, R.M., Santos Motta, J.V., Minten, G.C., Horta, B.L. and Gigante, D.P. (2015). Consumption of ultra-processed foods and their impact on the diet of young adults. Revista de Saude Publica, 49, 28.
https://doi.org/10.1590/S0034-8910.2015049005572

The Food Monitoring Group. (2012). International collaborative project to compare and track the nutritional composition of fast foods. BMC Public Health, 12, 559. https://doi.org/10.1186/1471-245812-559

Gupta, S., Lakshmi, A.J., Manjunath, M.N. and Prakash, J. (2005). Analysis of nutrient and antinutrient content of underutilized green leafy vegetables. $L W T$ -Food Science and Technology, 38(4), 339-345. https://doi.org/10.1016/j.1wt.2004.06.012

Kim, H.J. and Paik, H. (2012). Functionality and application of dietary fiber in meat products. Korean Journal for Food Science of Animal, 32(6), 695-705. https://doi.org/10.5851/kosfa.2012.32.6.695

Ladero, L., Cantero, V. and Ram, M.R. (2012). Assessment of different dietary fibers (tomato fiber, beet root fiber, and inulin) for the manufacture of chopped cooked chicken products. Journal of Food Science, 77(4), 346-352. https://doi.org/10.1111/ j.1750-3841.2011.02597.x

Ledikwe, J.H., Blanck, H.M., Khan, L.K., Serdula, M.K., Seymour, J.D., Tohill, B.C. and Rolls, B.J. (2005). Dietary energy density determined by eight calculation methods in a nationally representative United States population 1. Journal of Nutrition, 135 (2), 273-278. https://doi.org/10.1093/jn/135.2.273

Mikhail, W.Z.A., Sobhy, H.M., Khallaf, M.F., Ali, H.M.Z., El-askalany, S.A. and Ezz El-Din, M.M. (2014). Suggested treatments for processing high nutritive value chicken burger. Annals of Agricultural Sciences, 59(1), 41-45. https:// doi.org/10.1016/j.aoas.2014.06.006

Ramadhan, K., Huda, N. and Ahmad, R. (2011). Physicochemical characteristics and sensory properties of selected Malaysian commercial chicken burgers. International Food Research Journal, 18 (4), 1349-1357.

Ramadhan, K., Huda, N. and Ahmad, R. (2012). Physicochemical and sensory characteristics of burger made from duck surimi-like material. Poultry Science, 91(9), 2316-2323. https://doi.org/10.3382/ ps.2011-01747

Wong, W.C., Pui, C.F., Tunung, R., Cheah, Y.K., Nakaguchi, Y., Nishibuchi, M. and Son, R. (2012). Prevalence of Listeria monocytogenes in frozen burger patties in Malaysia. International Food Research Journal, 19(4), 1751-1756. 